\title{
The Study of the Main Milk Production Traits of Red Holstein Breed, Raised in Salaj County
}

\author{
Grigore ONACIU ${ }^{11}$, Eugen JURCO ${ }^{1) *}$ and Octavian NEGREA ${ }^{2)}$ \\ ${ }^{1)}$ Department of Cattle Breading, University of Agriculture Science and Veterinary Medicine of Cluj- \\ Napoca, 3-5 Manastur Street, 400372, Cluj-Napoca, Romania \\ ${ }^{2)}$ Department of Animal Pathology, University of Agriculture Science and Veterinary Medicine of Cluj- \\ Napoca, 3-5 Manastur Street, 400372, Cluj-Napoca, Romania \\ *Corresponding author, e-mail: jurco_eugen@yahoo.com
}

Bulletin UASVM Animal Science and Biotechnologies 72(2) / 2015

Print ISSN 1843-5262; Electronic ISSN 1843-536X

DOI:10.15835/buasvmcn-asb:11474

\begin{abstract}
In order to increase the quantity and quality of milk production, animal fertility and natality, many dairy farmers grow specialized dairy breeds, including Red Holstein breed, or practice some crossbreeding with those breeds. The aim of this work was to determine the production potential of Red Holstein cows, and milk quality, in terms of somatic cell count and total germ number. The study was conducted on a herd of 20 Red Holstein cows from the S.C. Agro Laura farm, Sălaj County, which was analysed in terms of quantity and quality of milk produced in 2012-2014. The amount of milk was estimated based on daily production obtained from the total number of milked cows, while milk quality was established based on milk samples collected monthly and analysed by standard procedure in a specialised laboratory. In the analysis performed we found that daily milk production was on average about $22.4 \mathrm{~kg} / \mathrm{head}$, while somatic cell count and total number of germs were within the standard limits of $136-506$ cells $/ \mathrm{ml} \mathrm{x} 10^{3}$, with an average of 258 cells $/ \mathrm{ml} \mathrm{x} 10^{3}$, and $24-279$ germs $/ \mathrm{ml} \mathrm{x} 10^{3}$, with an average of 120.5 germs $/ \mathrm{ml} \mathrm{x} 10^{3}$. This research has confirmed the good potential for milk production of the studied cattle breed, with the productive performance over $10,000 \mathrm{~kg}$ milk, close to the real genetic potential of the breed.
\end{abstract}

Keywords: cattle, milk quality, Red Holstein

\section{INTRODUCTION}

The main goal in the organization of breeding technology of dairy cows is to obtain quality products in terms of economic efficiency (Nistor $e t$ al., 2008) and animal welfare taking full advantage of the biologically productive potential of the animal, and of the zonal agricultural potential in terms of sustainable agriculture (Onaciu, 2013).

Due to its productive capacity, Holstein is the dominant dairy breed in Europe. In many countries, the yield per cow has more than doubled in the last 40 years, due to rapid progress in genetics and also in farm management (Oltenacu and Broom, 2010). In Romania, many dairy farmers grow, on the one hand, specialised dairy breeds, including the Red Holstein breed, and on the other hand, practice some crossbreeding using those breeds. The technology of dairy cow breeding is nothing more than a business, which - once launched - regardless of size, must operate at high performance parameters, and also provide economic comfort to the farmer, who embarks on an activity so complex and difficult to manage (Onaciu, 2013). The productive activity and economic results of dairy farms are largely influenced by the reproduction activity and which in turn is influenced by certain genetic factors such as breed, environmental factors, as well as management and technological factors (Maciuc et al., 2014).

\section{AIMS AND OBJECTIVES}

The purpose of this paper is to analyse the main characteristics of quality and compliance of 
Tab. 1. Quantity and quality of milk produced in 2012-2014 by the Red Holstein breed

\begin{tabular}{|c|c|c|c|c|c|c|}
\hline Traits & $\begin{array}{l}\text { Quantity of milk } \\
\text { collected monthly }\end{array}$ & $\begin{array}{c}\text { Fat } \\
(\mathrm{g} / 100 \mathrm{~g}) \\
\end{array}$ & $\begin{array}{l}\text { Protein } \\
(\mathrm{g} / 100 \mathrm{~g}) \\
\end{array}$ & $\begin{array}{l}\text { Solids not fat } \\
(\mathrm{g} / 100 \mathrm{~g})\end{array}$ & $\begin{array}{c}\mathrm{SCC} / \mathrm{ml} \mathrm{x} \\
10^{3} \\
\end{array}$ & $\begin{array}{c}\mathrm{TNG} / \mathrm{ml} \mathrm{x} \\
10^{3} \\
\end{array}$ \\
\hline $\operatorname{Mean}(\mathrm{X})$ & 10220 & 3.9 & 3.55 & 8.79 & 258.25 & 120.5 \\
\hline Standard error $\left(\mathrm{s}_{\mathrm{x}}\right)$ & 484.30 & 0.04 & 0.13 & 0.29 & 97.87 & 84.63 \\
\hline $\begin{array}{c}\text { Variation coefficient } \\
(\mathrm{V} \%)\end{array}$ & 16.38 & 1.29 & 3.73 & 3.31 & 37.89 & 70.23 \\
\hline Std Dev (s) & 1677.66 & 0.02 & 0.07 & 0.16 & 56.50 & 48.86 \\
\hline Min. & 7260 & 3.76 & 3.44 & 8.30 & 136 & 24 \\
\hline Max. & 12110 & 4.15 & 3.87 & 9.18 & 506 & 279 \\
\hline
\end{tabular}

raw cow's milk from S.C. Agro Laura farm, Sălaj County.

\section{MATERIALS AND METHODS}

The biological material is represented by a 20-head herd of dairy cows of Red Holstein breed, which was analysed in terms of quantity and quality of milk produced in 2012-2014. The amount of milk was estimated based on daily production obtained from the total number of milked cows, while quality assessment was based on monthly controls performed by sampling and analysed in the laboratory of Friesland Romania, based in Cluj-Napoca.

\section{RESULTS AND DISCUSSION}

The results highlighted the fact that in the period 2012 - 2014, the average monthly value of milk production was $10,220 \mathrm{~kg}$, with $3.9 \%$ fat, returning on average about $22.4 \mathrm{~kg} / \mathrm{head}$. The situation by seasons reveals that the greatest amount of milk is yielded in summer with a monthly average of $11,250 \mathrm{~kg}$, and the lowest amount of milk in winter $-8,970 \mathrm{~kg}$. In terms of milk quality regarding somatic cell count (SCC) and total number of germs (TNG), they were within the limits of $136-506$ cells $/ \mathrm{ml} \times 10^{3}$, with an

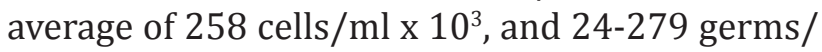
$\mathrm{ml} \mathrm{x} 10^{3}$, with an average of 120.5 germs $/ \mathrm{ml} \mathrm{x} 10^{3}$.

\section{CONCLUSION}

Performing a detailed analysis, we can conclude that the cattle population on the farm is well adapted to the operating conditions, and the productive performance of cows yielding over $10,000 \mathrm{~kg}$ milk places them close to their real genetic potential.

\section{REFERENCES}

1. Maciuc V, Creangă S, Chelmu SS. (2014). The reproductive capacity and specific applied biotechnologies in rendering cows reproduction efficient. Rom Biotechnol Lett, 19 (2): 9155-9161

2. Nistor E, Nistor Gh, Bampidis V. (2008). Phenotypic parameters of milk production in dairy romanian black spotted breed from Petresti-Alba farm. Scientific Papers Animal Science and Biotechnologies, Timisoara, (41): 460463.

3. Oltenacu PA, Broom DM. (2010). The impact of genetic selection for increased milk yield on the welfare of dairy cows. Animal Welfare, 19(S): 39-49, ISSN 0962-7286

4. Onaciu G. (2013). Cattle breeding. Publishing House Book House of Science, Cluj-Napoca 